\title{
Penguatan Partisipasi Perempuan dalam Pengendalian Resiko Kerusakan Lingkungan Hidup bagi Kelompok Ibu Rumah Tangga di Kelurahan Mbaumuku, Manggarai, Flores, NTT
}

\author{
Yosefina Rosdiana $\mathrm{Su}^{1}{ }^{*}$, Fatmawati ${ }^{2}$, Zephisius R. A. Ntelok ${ }^{3}$ \\ 1,2,3 Universitas Katolik Santu Paulus Ruteng, Flores, NTT
}

\section{A R T I C L E I N F O}

Article history:

Received 20 February 2019

Received in revised form

10 March 2019

Accepted 30 April 2019

Available online 27 May 2019

\section{Kata Kunci:}

partisipasi, lingkungan, ibu rumah tangga, perempuan

Keywords:

participation, environment, housewives, women

\begin{abstract}
A B S T R A K
Perempuan dan lingkungan adalah dua komponen kehidupan yang telah terikat secara alamiah. Karenanya, perempuan memiliki potensi dan posisi strategis yang dapat diberdayakan dalam menanggapi isu-isu pemeliharaan lingkungan. Akan tetapi, di berbagai kalangan masyarakat, posisi perempuan, terutama mereka yang berprofesi sebagai ibu rumah tangga masih dianggap tidak menguntungkan yang kemudian membatasi akses mereka untuk berpartisipasi dalam sektor publik termasuk untuk berperan serta dalam gerakan-gerakan peduli lingkungan. Bagi beberapa kelompok ibu rumah tangga, kerentanan posisi perempuan ini juga disebabkan oleh dominasi kuat budaya patriarki yang telah berakar dalam masyarakat. Paradigma ini juga telah melemahkan posisi perempuan dan cenderung menjadikannya sebagai kelompok yang termarginalkan. Mengangkat masalah pengelolaan sampah, artikel ini memaparkan sebuah upaya pendampingan berbasis gender bagi kelompok ibu rumah tangga agar kelompok ini dapat menjadi tokoh sentral yang mampu membangun sinergi dengan semua komponen masyarakat dalam mengendalikan kerusakan lingkungan hidup yang disebabkan oleh kesalahan dalam sistem pengolahan sampah.
\end{abstract}

\section{A B S T R A C T}

Women and environment were naturally bound. Therefore, women had a potential and strategic position to be empowered in responding the issues of environmental preservation. However, in many societies, the position of women, especially those who occupied as housewife, were still considered unprofitable and it restricted their access to participate in public sectors, including in environmental preservation movements. For some women, the vulnerability of their position was also caused by the strong dominance of patriarchal culture that had taken its root in the society. This paradigm enervated women's position and tended to be end up as marginalized group in a society. concerning the issue of waste management, this article described the gender based environmental advisory for group of housewife, which aimed at supporting them to take part as the central figure who can build the synergy with all components of society in restraining the environmental damage caused by the inappropriate waste management system.

\footnotetext{
* Corresponding author.

E-mail addresses: rosdianasu@gmail.co.id (Yosefina Rosdiana Su)
} 


\section{Pendahuluan}

Kehidupan manusia tidak bisa dipisahkan dari lingkungannya. Baik lingkungan alam maupun lingkungan sosial. Manusia dari lingkungan hidup (alam) memiliki hubungan sangat erat. Keduanya saling memberi dan menerima pengaruh besar satu sama lain. Pengaruh alam terhadap manusia lebih bersifat pasif, sedangkan pengaruh manusia terhadap alam lebih bersifat aktif. Manusia memiiki kemampuan eksploitatif terhadap alam sehingga mampu mengubahnya sesuai yang dikehendakinya (Christie, 2013). meskipun pemerintah telah menetapkan berbagai kebijakan terkait lingkungan hidup termasuk melalui disahkannya UU Lingkungan Hidup yang telah diperbaharui yakni UU No. 32 Tahun 2009 bagi perlindungan dan penyelamatan lingkungan hidup, kerusakan lingkungan hidup tetap menjadi persoalan krusial yang terus berkembang di berbagai wilayah di seluruh Indonesia dan sangat mendesak untuk diselesaikan. Meningkatnya resiko kerusakan lingkungan tidak dapat dipisahkan dari kesalahan praktek pengolahan sampah, termasuk pengolahan sampah rumah tangga.

Menurut Edison (2016) sampah cukup menjadi masalah pada tempat yang padat penduduknya. Kesadaran masyarakat untuk membuang sampah pada tempat pembuangan yang telah disediakan masih rendah, apalagi untuk mengolahnya. Pada dasarnya, pemerintah telah menetapkan kebijakan pengolahan sampah melalui UU Pengelolaan Sampah no 18 tahun 2008 yang menegaskan ketentuan umum dalam pengolahan sampah. UU ini mengatur pengolahan sampah langsung dari sumbernya, yaitu sampahsampah yang berasal dari timbulan sampah, seperti rumah tangga, industri, pusat perbelanjaan, perkantoran dan sebagainya. Melalui UU Pengelolaan Sampah ini, pememrintah juga menegaskan tentang pegolahan sampah dengan metode 3R (Re-use, Reduce, \& Recycle) untuk menghindari penumpukan volume sampah. Menurut Ediana (2018) pengetahuan yang diberikan kepada masyarakat mengenai pengolahan sampah 3R merupakan paradigma baru yang membutuhkan keterlibatan masyarakat dalam mendukung program pembangunan khususnya di bidang kesehatan lingkungan. Menurut Widiarti (2012) peningkatan jumlah sampah terjadi seiring deret ukur sedangkan ketersedian lahan Tempat Pembuangan Akhir (TPA) sampah mengikuti deret hitung. Hal ini mengakibatkan lahan TPA memiliki umur yang pendek karena tidak mampu lagi menampung sampah yang ada. Rendahnya teknologi yang dimiliki dan lemahnya infrastruktur menimbulkan permasalahan sampah yang cukup rumit terutama di negara berkembang seperti Indonesia. Konsep pengelolaan sampah 3R sudah tidak asing lagi di telinga masyarakat. Konsep ini sangat cocok diterapkan di negara berkembang yang karena keterbatasan teknologi maka harus memberdayakan masyarakat sebagai pelaku yang menghasilkan sampah. Namun, pada kenyataannya penerapan 3R dalam kehidupan sehari-hari masih jauh dari yang diharapkan. Prinsip Reduce, Reuse, Recycle (3R) yang menjadi ujung tombak dalam menangani sampah di lingkungan masyarakat seakan hanya slogan yang tidak mengena.

Menurut Munawwaroh (2017) risiko adalah sesuatu yang mengarah pada ketidakpastian atas terjadinya suatu peristiwa selama selang waktu tertentu yang mana peristiwa tersebut menyebabkan suatu kerugian baik itu kerugian kecil yang tidak begitu berarti maupun kerugian besar yang berpengaruh. Seiring dengan merebaknya isu-isu kerusakan lingkungan hidup oleh produksi sampah yang kian sulit terkendali, hal positif yang dapat ditangkap dalam perkembangan hari ini adalah, lahirnya berbagai gerakan peduli lingkungan yang digagas oleh pemerintah maupun komunitas-komunitas masyarakat diberbagai wilayah termasuk gerakan-gerakan yang menyasar kelompok perempuan. Dalam hal ini, perempuan dianggap sebagai kelompok masyarakat yang memiliki potensi yang kuat untuk melakukan perubahan bagi lingkungannya. Karenanya, kelompok perempuan kini mulai mendapatkan perhatian yang serius dan dalam kerangka penyelesaian persoalan lingkungan hidup.

Lingkaran budaya patriarkhi yang menempatkan peran laki-laki pada posisi superior sedangkan perempuan hanya menjadi subordinat menjadi salah satu faktor yang mendasari gerakan pemberdayaan terhadap perempuan. Tugas-tugas domestik seperti mencuci, memasak, membersihkan rumah, atau menyediakan pangan bagi seluruh anggota keluarga menjadi salah satu peran sosial yang melekat dalam diri perempuan di berbagai kalangan masyarakat dengan budaya patriarki, termasuk dalam budaya Manggarai, Flores, NTT. Aktifitas dosmetik yang dijalankan oleh kelompok perempuan juag menempatkan mereka sebagai kelompok yang sangat rentan terkena dampak kerusakan lingkungan karena limbah domestic yang tidak dikelola dengan benar merupakan salah satu faktor utama yang berkontribusi terhadap resiko pencemaran dan kerusakan lingkungan.

Secara fisiologis, Sarwono (2010;179), menyebutkan empat hal mendasar yang mengikat perempuan dan alam. Pertama, karena peran perempuan berkaitan dengan berbagai upaya merawat dan menjaga keberlangsungan alam semesta dan masa depan manusia. Kedua, posisi perempuan di wilayah domestik juga ikut menentukan kualitas generasi masa depan. Ketiga, psikologi perempuan sebagai ibu membuahkan cara berpikir yang lebih relasional dan konkrit dibanding dengan laki-laki, dan keempat, kaum perempuan yang bertanggung jawab terhadap wilayah domestik punya banyak andil dalam 
mengurangi jumlah sampah dengan melakukan program 3R yaitu, reduce, reuse, dan recyle. Fungsi dan peran strategis perempuan inilah yang menjadi alasan mendasar mengapa partisipasi kelompok ini dalam mengatasi persoalan lingkungan hidup harus diperkuat.

Kelurahan Mbaumuku merupakan salah satu kelurahan yang terletak di wilayah kecamatan Langke Rembong, Kabupaten Manggarai, Flores, NTT. Meningkatnya pertumbuhan ekonomi kreatif di wilayah Manggarai kini telah membuka aneka peluang usaha yang dijalankan oleh penduduk lokal maupun penduduk pendatang. Pertumbuhan ekonomi di wilayah ini secara signifikan telah berdampak pada pertumbuhan jumlah penduduk yang tidak hanya berasal dari wilayah sekitar, tetapi juga dari luar NTT seperti, Jawa, NTB, Sumatra, dan Sulawesi. Wilayah sasaran merupakan pusat kegiatan ekonomi masyarakat Manggarai. Karena lokasinya yang strategis, wilayah ini juga menjadi sasaran pemukiman bagi masyarakat pendatang sehingga populasi penduduk di wilayah ini terus meningkat setiap tahunnya. Menjamurnya titik-titik usaha perekonomian di wilayah ini juga berdampak pada peningkatan volume sampah yang diproduksi setiap harinya.

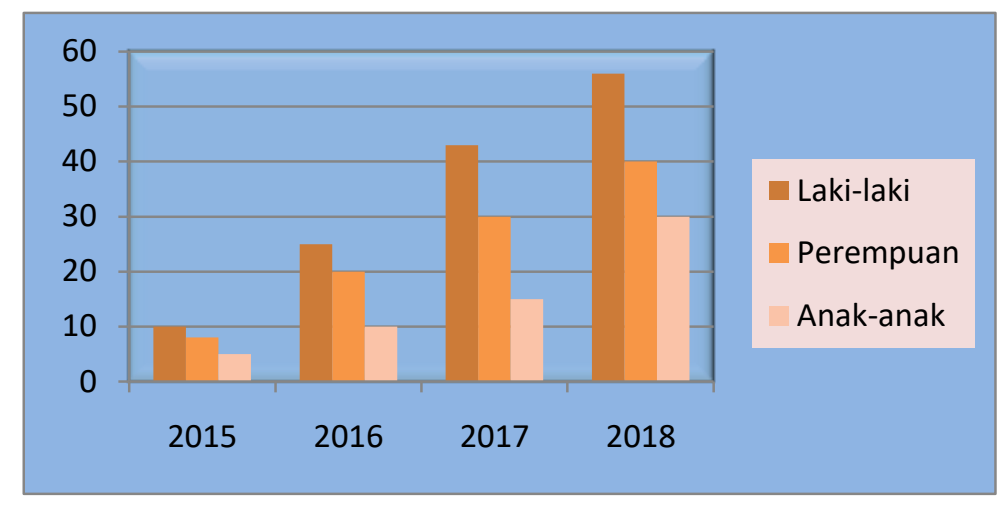

Gambar 1. Diagram Data Pertumbuhan Penduduk Pendatang di Kelurahan Mbaumuku

Permasalahan pada umumnya berkaitan erat dengan timbunan sampah, kepedulian masyarakat yang masih rendah sehingga suka berperilaku membuang sampah sembarangan, keengganan untuk membuang sampah pada tempat yang sudah disediakan. Perilaku yang buruk ini seringkali menyebabkan bencana di musim hujan karena darainase tersumbat sampah sehingga terjadi banjir (Hardiatmi, 2011). Sejauh ini, penanggulangan sampah yang dilaksanakan di wilayah ini belum bersifat partisipatif. Pemerintah kelurahan belum mampu melibatkan semua komponen masyarakat untuk terlibat secara aktif dalam pengendalian dan penanggulangan sampah. Program-program penyuluhan dan kesehatan lingkungan masih menjadi strategi utama dalam menanggulangi sampah. Strategi non-partisipatif ini dinilai kurang mampu memberikan dampak pada perubahan prilaku dan pola pikir masyarakat tentang resiko kerusakan lingkungan, terutama yang disebabkan oleh kesalahan dalam pengolahan sampah.

Sebagai institusi pemerintahan yang bersentuhan langsung dengan persoalan di akar rumput, kelurahan Mbaumuku memiliki sebuah organisasi pemberdayaan masyarakat yang melibatkan kelompok perempuan yaitu organisasi PKK. Organisasi PKK di kelurahan ini pada dasarnya dimotori oleh ibu-ibu yang berprofesi sebagaiibu rumah tangga, dan pada umumnya berpendidikan SMA. Dalam pelaksanaannya, organisasi perempuan ini belum berjalan sesuai dengan fungsi dan perannya sebagai mitra kerja pemerintah dalam menyelesaikan persoalan-persoalan sosial kemasyarakatan dan masih dipandang sebagai kelompok arisan ibu rumah tangga dengan kegiatan-kegiatan yang tidak direncanakan, dilaksanakan, dan dievaluasi secara sistematis dan berkelanjutan. 


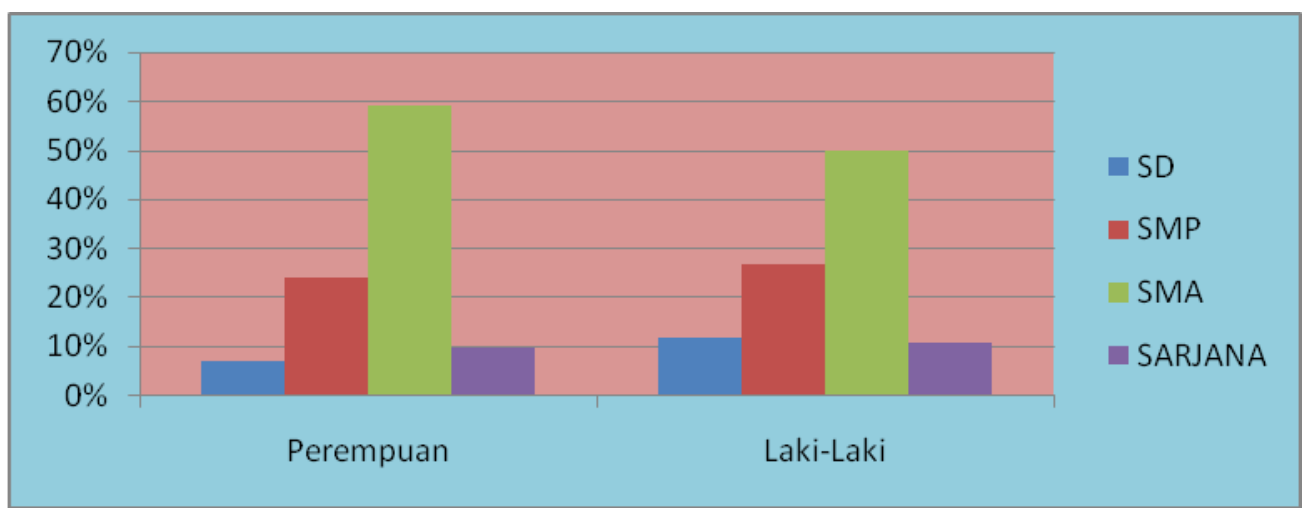

Gambar 2. Diagram Rata-Rata Latar Belakang Pendidikan Masyarakat di Wilayah Kuwu

Selain organisasi PKK, komunitas perempuan lainnya yang terdapat di wilayah kelurahan ini adalah para kader posyandu. Kelompok ini dianggap berpotensi untuk diberdayakan karena keterlibatannya sebagai tenaga penyuluh kesehatan di kelurahan ini. Kelompok-kelompok perempuan ini harus mendapatkan perhatian dan diberikan kesempatan untuk terlibat dalam menyelesaikan persoalan sampah di wilayah ini. Kelompok ini perlu diedukasi dan diperkaya dengan informasi dan pengetahuan terkait lingkungan dan resiko kerusakannya agar dapat mengambil bagian dalam upaya pengendalian dan penanggulangannya. Persoalan sampah adalah persoalan bersama dan harus ditanggulangi melalui kerjasama yang partisipatif. Oleh karena itu, kelompok perempuan harus didorong untuk terlibat dan terus menguatkan kapasistasnya melalui berbagai program pendampingan maupun pelatihan keterampilan mengendalikan dan mengolah sampah.

\section{Metode}

Huraerah (2011) menyatakan bahwa partisipasi menuntut tiga hal penting yaitu mental and emotional involvement (keterlibatan mental dan emosi), motivation to contribute (dorongan untuk berkontribusi), dan acceptance of responsibility (penerimaan tanggung jawab). Ketiga hal ini menjadi kunci keberhasilan kegiatan pemberdayaan masyarakat yang harus dipahami oleh semua pihak, terutama masyarakat sendiri. Pendekatan yang tepat akan berpengaruh dalam menjaring partisipasi kelompok sasaran. Oleh karenanya, dalam pelaksanaanya, program ini menekankan pada pendekatan berbasis gender. Pendekatan ini memberikan peluangan kepada setiap anggotanya yang terdiri dari para ibu rumah tangga untuk berpartisipasi dalam memberikan gagasan, ide, dan tindakan nyata dalam menyelesaikan persoalan lingkungan hidup yang disebabkan oleh kesalahan dalam sistem pengolahan sampah. Focus Group Discussion yang dilakukan selama proses pendampingan ini telah menjadi forum informasi dan edukasi bagi kelompok perempuanyang terus didorong untuk terlibat dan menyadari tanggungjawab mereka terhadap pelestarian lingkungan hidup. Selain diskusi, kegiatan pendampingan yang dilakukan juga diberikan dalam bentuk pelatihan-pelatihan ketrampilan mengolah sampah yang dapat dimulai dari rumahnya masing-masing.

\section{Hasil dan pembahasan}

Perempuan memiliki potensi untuk menjadi agen perubahan yang dapat mempengaruhi kualitas lingkungan hidup. Dalam beberapa sesi diskusi yang dilakukan bersama kelompok sasaran, para peserta sangat antusias dalam memetakan persoalan-persoalan mendasar dalam praktek pengendalian sampah yang terjadi di sebagian besar rumah tangga dan menawarkan gagasan-gagasan solutif dalam menaggulangi persoalan sampah di wilayahnya. Para perempuan ini berpandangan, pengolahan sampah yang selama ini diberlakukan hanyalah memindahkan sampah darirumahke tempatsampahumum yang kemudiandipindahkanlagiketempat pembuangan akhir yang disediakan oleh pemerintah kabupaten, artinya, sampah-sampah tersebut belum dikelola secara benar dan baik oleh masyarakat.

Mereka juga mengidentifikasi bahwa sampah-sampah rumah tangga di wilayah ini cenderung ditumpuk begitu saja tanpa dipisahkan berdasarkan jenisnya. Para perempuan ini sepakat bahwa masih banyak Ibu rumah tangga yang belum memahami hakikat sampah rumah tangga dan resiko-resiko pencemaran lingkungan yang dapat disebabkan oleh kesalahan pengolahannya. 

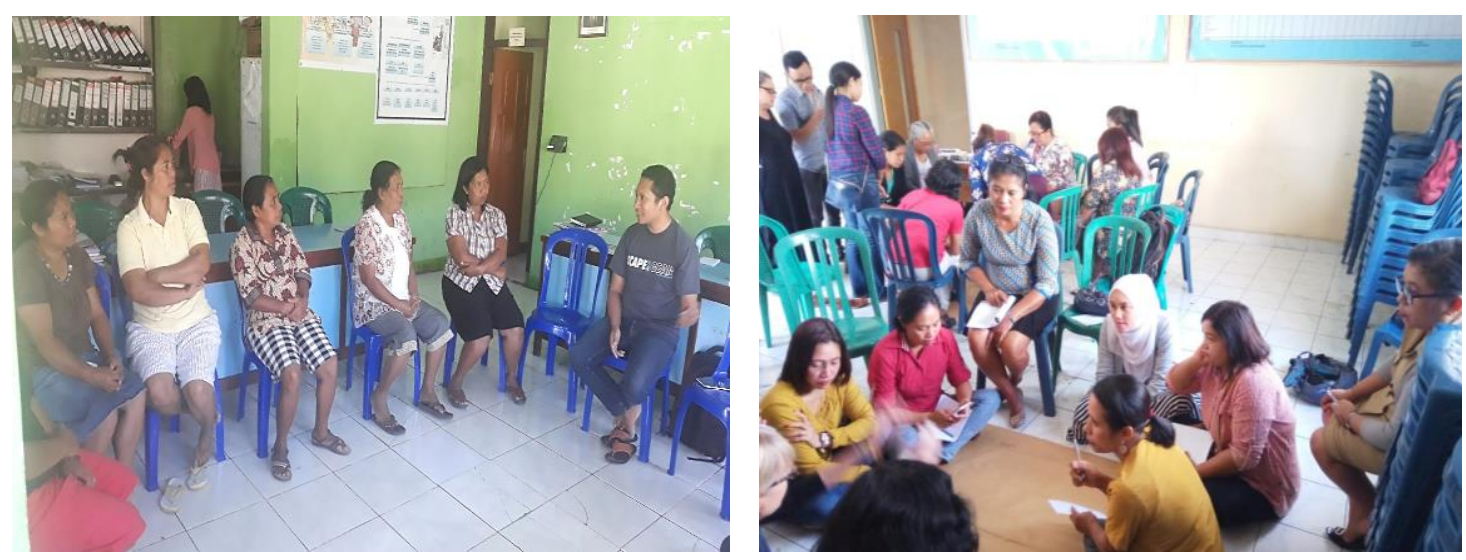

Gambar 3. FGD Pemetaan Persoalan dan Solusi Pengolahan Sampah di Wilayah Sasaran
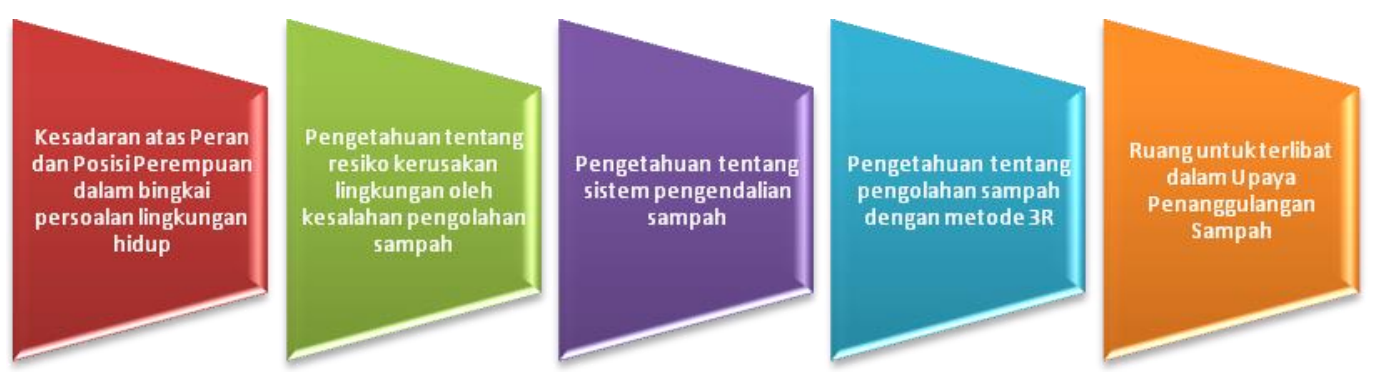

Gambar 4. Diagram Pemetaan Persoalan Perempuan Terkait Lingkungan Hidup

Berdasarkan persoalan-persoalan tersebut, para peserta menyampaikan beberapa gagasan penting terkait penguatan partisipasi perempuan dalam pengelolaan sampah yaitu:

a. Sebagai ibu yang mengatur segala urusan rumah tangga, perempuan harus membiasakan diri melakukan hal-hal yang dapat mengurangi resiko kerusakan lingkungan yang harus diikuti oleh seluruh anggota keluarga.

b. Dalam mengolah sampah dalam rumah tangga, perempuan harus membiasakan diri untuk memilah sampah berdasarkan kategorinya seperti sampah organik dan non-organik dengan cara menyediakan tempat sampah khusus untuk pembuangan sampah dengan jenis yang berbeda tersebut.

c. Setiap ibu adalah pendidik bagi anak-anak mereka, karenanya, seorang ibu harus mampu menanamkan nilai-nilai kepedulian lingkungan kepada anak-anaknya sejak dini, agar anak memiliki kepekaan dan kepedulian terhadap lingkungan hidup sejak dini.

d. Perempuan harus bekerjasama dengan semua komponen masyarakat untuk bersama-sama mengatasi persoalan sampah dan lingkungan hidup di sekitarnya termasuk dengan membentuk komunitas lingkungan yang menginspirasi perempuan lainnya agar peduli dan melestarikan lingkungan sekitar pemukiman mereka.

e. Perempuann perlu menjadi pioner yang mendorong gerakan-gerakan 3R di lingkungannya, agar persoalan sampah dapat diselesaikan bersama-sama.

Untuk itu, perempuan perlu dibekali dengan keterampilan mengolah sampah dengan metode yang telat dan efisien. Salah satu langkah solutif yang ditawarkan melalui kegiatan ini adalah pelatihan khusus pengolahan sampah berbasis 3R (reduce, reuse, recycle) untuk produk sampah organik dan non-organik. Kegiatan pelatihan ini juga diisi dengan diskusi menarik tentang berbagai kemungkinan bahan dan hasil olahan sampah yang bisa dilakukan oleh para ibu.

\section{A. Pelatihan Pengolahan Sampah Organik}

Pelatihan pengolahan sampah melalui metode 3R yang dilakukan dalam kegiatan ini adalah pelatihan mengolah sampah organik kulit pisang menjadi bahan pangan bernilai ekonomis. Sebagaimana diuraikan sebelumnya, wilayah ini adalah pusat industri rumah tangga yang juga menjadi penghasil 
sampah dalam jumlah yang besar, dimana, masyarakat dapat dengan mudah menemukan gerobakgerobak gorengan yang berjumlah belasan unit. Menjamurnya pedagang gorengan di wilayah sasaran meningkatkan produksi limbah kulit pisang. Dalam prakteknya, limbah kulit pisang dalam jumlah yang sangat banyak ini belum diolah secara efisien. Kelompok perempuan dalam kegiatan ini melihat sampah kuli pisang yang dihasilkan oleh pedagang gorengan adalah sampah potensial yang dapat di daur ulang. Untuk itu, melaui program ini, para ibu difasilitasi untuk mendapatkan informasi dan pengetahuan praktis bagaimana mengolah sampah kulit pisang menjadi bahan pangan yang sehat dan dapat dikonsumsi oleh anggota keluarga yang lainnya ataupun dikembangkan dengan tujuan ekonomis.

Kulit Pisang memiliki kandungan senyawa kimia yang tinggi. Berbagai penelitian menunjukkan bahwa ekstrak air kulit pisang kaya akan senyawa serotonin. Wilar (2014) menjelaskan bahwa, serotonin adalah neurotransmitter yang diperlukan tubuh kita terutama pada orang yang menderita depresi. Pada penderita depresi kadar serotonin berkurang hal ini dikarenakan aktivitas enzim monoamine oksidase yang terlalu kuat dalam menguraikan amin biogenik seperti serotonin ini. Kekurangan serotonin dapat dihilangkan dengan pemberian ekstrak air kulit pisang yang kaya akan senyawa serotonin.
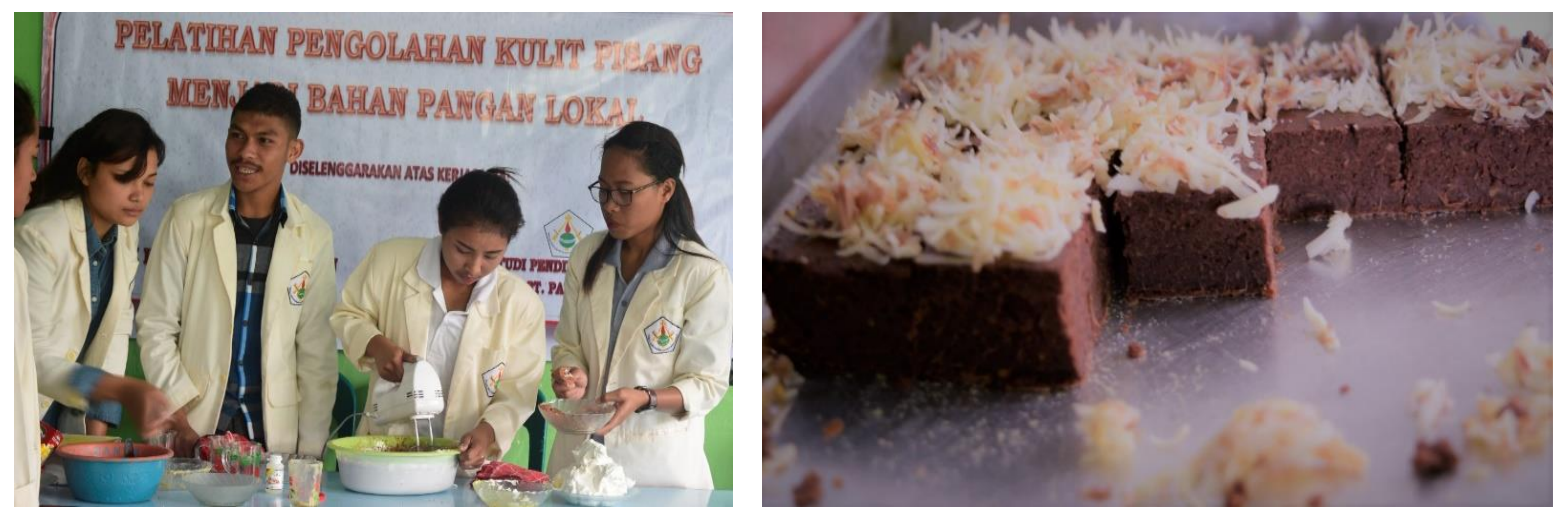

Gambar 5. Pelatihan Pengolahan Kulit Pisang menjadi Brownis Kulit Pisang

Selain itu, Munajin dalam Wilar (2014) juga menjelaskan bahwa, kandungan unsur gizi kulit pisang cukup lengkap, seperti karbohidrat, lemak, protein, kalsium, fosfor, zat besi, vitamin B, vitamin C dan air. Unsur-unsur gizi inilah yang dapat digunakan sebagai sumber energi dan antibodi bagi tubuh manusia sehingga aman untuk dikonsumsi sebagai sebagai bahan baku pembuatan makanan.

Kegiatan pelatihan ini memberikan pengetahuan dan informasi kepada para peserta terhadap nilai gizi yang terkandung dalam kulit pisang. Sifat basah dan lembut yang dimiliki oleh adonan kulit pisang menjadikan panganan ini menjadi padat dan lembut, sehingga dalam pembuatannya, para ibu tidak perlu menambahkan terigu dan mentega/butter. Brownis ini sangat cocok dikonsumsi oleh para penderita penyakit kolesterol maupun diabetes, karena sifatnya yang rendah gula dan karbohidrat, tetapi juga tetap sehat dikonsumsi oleh anak-anak dan anggota keluarga yang lainnya. Para peserta sangat antusias dan terlibat aktif dalam diskusi dan tanya jawab terkait metode pengolahan limbah kulit pisang termasuk produk lain yang dapat dihasilkan dari limbah kulit pisang dan mengusulkan adanya tindak lanjut dari kegiatan ini, terutama agar dapat didorong menjadi salah satu peluang usaha ekonomi kreatif bagi para perempuan di wilayah ini.

\section{B. Pelatihan Pengolahan Sampah Non-Organik}

Selain pedagang gorengan, wilayah ini juga memiliki potensi sampah non-organik hasil usaha konveksi rumahan yang terdapat di 5 titik usaha di wilayah ini. Kain perca yang merupakan sisa usaha konveksi merupakan jenis limbah padat anorganik yang tidak dapat membusuk sehingga mendaur ulangnya menjadi sesuatu yang berbeda dan dapat dimanfaatkan kembali merupakan jalan terbaik untuk mengatasi menumpukan sampah jenis ini. Sampah berupa kain sintetis adalah termasuk sampah anorganik yang paling sulit didaur ulang oleh bumi kita. Dengan memanfaatkannya menjadi sesuatu yang bisa digunakan kembali akan memberi dampak yang sangat baik bagi bumi yaitu mengurangi efek pemanasan global (Devanti, 2017). Oleh karenanya, program ini juga menawarkan pelatihan langsung pengolahan kain perca menjadi karpet pelangi. 

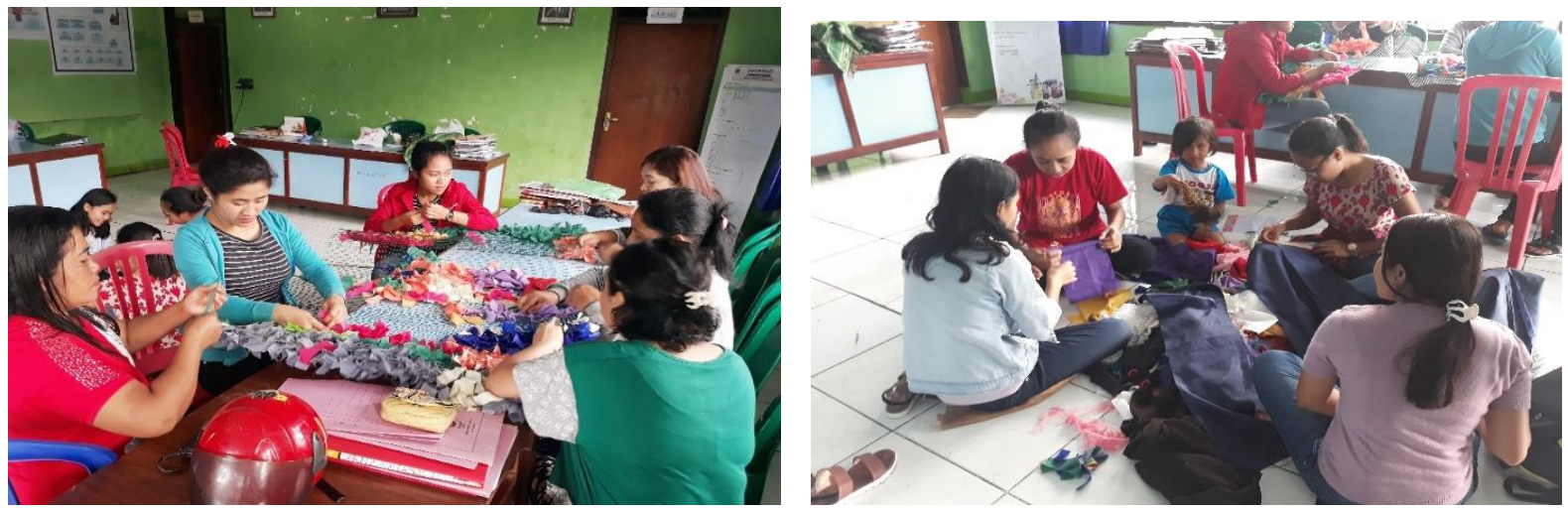

Gambar 6. Praktek Pembuatan Karpet dari Kain Perca

Dalam pelaksanaannya, para perempuan di kelompok sasaran mendapatkan informasi terkait resiko limbah sintesis bagi lingkungan hidup apabila tidak dioleh dengan benar. kegiatan pembuatan karpet dari kain perca ini memakan waktu yang cukup lama yaitu 2 bulan. Limbah padat anorganik seperti kain perca tidak dapat membusuk karena tidak adanya aktivitas mikroorganiasme pengurai. Oleh karenanya limbah padat jenis ini sebaiknya didaur ulang agar dapat dimanfaatkan kembali. Pada dasarnya, kain perca dapat diolah menjadi berbagai macam produk bernilai ekonomis, baik itu untuk aksesoris, fashion, hingga kebutuhan di dalam rumah tangga. Salah satu olahan kain perca yang dapat dicoba oleh para ibu adalah memanfaatkan kain-kain sisa ini untuk dijadikan karpet lantai. Cara pembuatannya pun sangat sederhana dan tidak membutuhkan biaya yang mahal. Para ibu hanya membutuhkan potongan-potongan kain perca dan kawat untuk menyusunnya potongan kain sudah digunting yang kemudian dijalin menjadi sususan karpet.
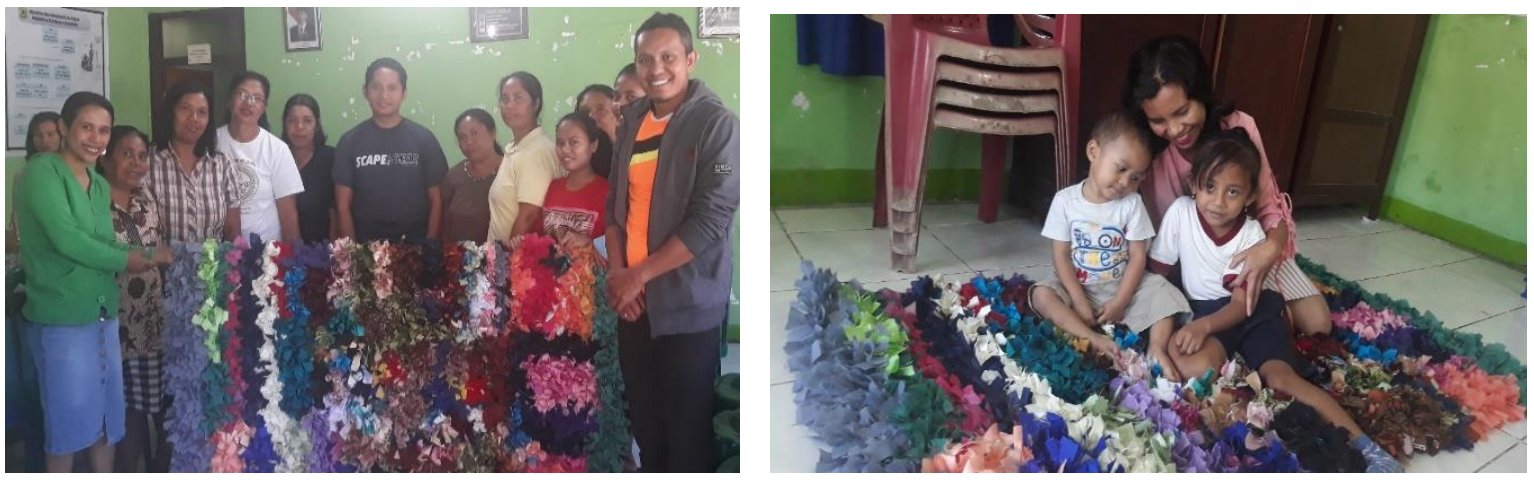

Gambar 7. Karpet Pelangi Karya Ibu-Ibu Rumah Tangga Kelurahan Mbaumuku

Karpet perca ini disebut karpet pelangi karena terdiri dari susunan kain perca yang berwarna-warni. Susunan kain yang berwarna-warni ini menjadikan karpet ini tampak cantik dan menarik. Warna-warni kain perca ini akan menambah kesan hangat dan ceria saat digunakan sebagai furniture rumah tangga.

\section{Simpulan dan saran}

Peran dan partisipasi perempuan dalam mengatasi persoalan lingkungan tidak boleh dipandang sebelah mata. Karakteristik yang melekat dalam diri perempuan yaitu ketekunan, kemauan, integrasi, dan control diri yang kuat adalah potensi utama yang harus terus di dorong dan diberdayakan bagi penyesaian masalah lingkungan hidup terutama dalam mengimplementasikan nilai-nilai efisiensi pengolahan sampah melalui metode 3R. Oleh karena itu, kelompok ini perlu mendapatkan edukasi dan pendampingan yang serius agar dapat menjadi agen perubahan dalam mengatasi dan mengendalikan produksi sampah.

Kelompok perempuan memang sering menjadi sasaran bagi penyelesaian masalah sampah karena perempuan dipandang lebih banyak berhubungan dengan sampah dalam aktifitas-aktifitas domestik yang dilakukannya setiap hari. Selain itu, keterampilan dan kreatifitas yang dimiliki oleh kaum perempuan membuat mereka dipandang mampu untuk menerapkan konsep-konsep pengolahan sampah dari mengurangi, menggunakan kembali, sampai dengan mendaur ulang sampah. Akan tetapi, kegiatankegiatan dan pendampingan kepada kelompok perempuan seharusnya tidak semata-mata menjadikan 
perempuan sebgai pihak yang paling bertanggungjawab terhadap sampah tetapi lebih menekankan pada peningkatan kapasitas kelompok perempuan agar mereka mampu mnggerakkan semua komponen dalam masyarakat agar bersama-sama terlibat aktif dan penyelesaian persoalan sampah dan lingkungan hidup pada umumnya.

\section{Daftar Rujukan}

Christie, Yosef Anata, La Sina, Rika Erawaty. 2013. Dampak Kerusakan Lingkungan Akibat Aktifitas Pembangunan Perumahan (Studi Kasus di Perumahan Palaran City Oleh PT. Kusuma Hady Property). Jurnal Beraja Niti Vol. 2 Nom. 11 Hal. 1-21. Tersedia Pada : https://media.neliti.com/media/publications/.

Devanti, Yeni Mardyana, 2017, Peengolahan Limbah Konveksi untuk Meningkatkan Pendapatan Ibu Rumah Tangga Miskin (IRTM), Jurnal pengabdian Kepada Masyarakat IPTEKS, Vol 3. No 1. Juni 2017.

Ediana, Dina, Fitria Fatma, dan Yuniliza. 2018. Analisis Pengolahan Sampah Reduce, Reuse, Recycle (3R) pada Masyarakat di Kota Payakumbuh. Jurnal Endurance Vol. 3 No. 2 Hal. 238-246. Tersedia Pada : http://ejournal.kopertis10.or.id/index.php/endurance/article/view/2771.

Edison, dan Ricvan Dana Nindrea. 2016. Faktor-Faktor yang Berhubungan dengan Penerapan 3R (Reduce, Reuse, dan Recycle) pada Sampah Rumah Tangga di Kabupaten Solok. Jurnal Medika Saintika Vol. 7 No. 2 Hal. 1-10. Tersedia Pada : http://syedzasaintika.ac.id/jurnal.

Hardiatmi, S. 2011. Pendukung Keberhasilan Pengelolaan Sampah Kota. INNOFARM. Jurnal Inovasi Pertanian, 10(1): 50-66.

Huraerah, Abu.2011. Pengorganisasian dan Pengembangan Masyarakat, Model dan Strategi pembangunan Berbasis Kerakyatan. Bandung: Buku Pendidikan-Anggota IKAPI.

Mulasari, S.A. 2012. Hubungan tingkat Pengetahuan dan Sikap Terhadap Perilaku Masyarakat dalam Mengelola Sampah Di Dusun Padukuhan Desa Sidokarto Kecamatan Godean Kabupaten Sleman Yogyakarta. Jurnal Kesmas, 6(3): 204-211.

Munawwaroh, Zahrotul. 2017. Analisis Manajemen Risiko pada Pelaksanaan Program Pendidikan dalam Upaya Meningkatkan Mutu Pendidikan. Jurnal Administrasi Pendidikan Vol. XXIV No.2 Hal. 71-79. Tersedia Pada : http://ejournal.upi.edu/index.php/JAPSPs/article/view/8295.

Sarwono, B.K. 2010. Pemaknaan Isu Pemanasan Global dan Lingkungan di Media oleh Kaum Perempuan Urban.http://repository.upnyk.ac.id/758/1/Pemaknaan_Isu_Pemanasan_Global_dan_Lingkungan_ di_Media_oleh_Kaum_Perempuan_Urban.pdf. 18 April 2019 (20.30).

Undang-Undang Nomor 23 Tahun 1997 tentang Pengelolaan Lingkungan Hidup.

Undang-Undang No. 18 Tahun 2008 tentang Pengelolaan Sampah.

Widiarti, Ika Wahyuning. 2012. Pengelolaan Sampah Berbasis "Zero Waste" Skala Rumah Tangga Secara Mandiri. Jurnal Sains dan Teknologi Lingkungan Vol. 4, No. 2 Hal. 101-113. Tersedia Pada : https://media.neliti.com/media/publications/128691.

Wilar, G., Indriyati, W. dan Subarnas. 2014. Pemanfaatan Dan Pengolahan Limbah Kulit Pisang Menjadi Permen Kulit Pisang Yang Berkhasiat Antidepresi Dalam Upaya Pemberdayaan Kesehatan Dan Perekonomian Masyarakat Desa Di Kecamatan Karang Tengah Kabupaten Cianjur. Dharmakarya: Jurnal Aplikasi Ipteks untuk Masyarakat.Vol. 3, No. 1, Mei 2014: 5-8. 